\title{
RFLP of 16S-ITS rDNA region to differentiate Lactobacilli at species level
}

\author{
Elif Yavuz ${ }^{1}$, Hatice Gunes ${ }^{2}$, Cisem Bulut ${ }^{1}$, Sebnem Harsa ${ }^{1}$ and A. Fazil Yenidunya ${ }^{2, *}$ \\ ${ }^{1}$ Biotechnology and Bioengineering Programme, Izmir Institute of Technology, 35430 Gulbahce, Izmir, Turkey \\ ${ }^{2}$ Department of Biology, Science Faculty, Izmir Institute of Technology, 35430 Gulbahce, Izmir, Turkey \\ *Author for correspondence: Tel.: +90-232-750-7545, Fax:+90-232-750-7509, E-mail: afazilyenidunya@iyte.edu.tr
}

Received 05 November 2003; accepted 01 January 2004

Keywords: Lactic acid bacteria, restriction fragment length polymorphism, similarity analysis

\section{Summary}

The 16S-ITS (internal transcribed spacer) region of the rrn operon was amplified by polymerase chain reaction (PCR). The amplification products were analysed by restriction fragment length polymorphism (RFLP) using a set of restriction enzymes, $A l u \mathrm{I}, \mathrm{HaeIII}$, and TaqI. Restriction pattern analyses revealed that TaqI restriction enzyme could clearly differentiate the nine reference strains of Lactobacillus used in the study.

\section{Introduction}

In most prokaryotes the ribosomal RNA genes reside sequentially in the chromosome (16S-23S-5S) and they are transcribed as a single polycistronic RNA molecule (Luz et al. 1998). The 16S rRNA gene sequence has been used for assessing bacterial phylogenies at genus level (Abd-El-Haleem et al. 2002; Shaver et al. 2002). Below the genus level, additional rDNA sequences have been necessary. The intergenic/internal transcribed spacer (ITS), also known as the intergenic spacer region (ISR) (Jensen et al. 1993; Fisher \& Triplett 1999; Daffonchio et al. 2000; Toth et al. 2001; Abd-El-Haleem et al. 2002; Shaver et al. 2002) between $16 \mathrm{~S}$ and $23 \mathrm{~S}$ rDNA genes, includes both conserved and highly variable sequence motifs, such as tRNA genes, and anti-terminators (boxA) (Abd-El Haleem et al. 2002). ITS is generally found in multiple copies in most bacterial genomes. Since ITS are hypervariable with respect to adjacent genes, they can differentiate between multiple operons in the cell (Daffonchio et al. 1998). The size of the spacer has been found to differ considerably among different species, and even among the different operons within a single cell (Garcia-Martinez et al. 1999). Amplification size polymorphisms of the ITS alone have been used for identification at the species level (Jensen et al. 1993; Cho \& Tiedje 2000; Abd-El Haleem et al. 2002).

In the present work, the 16S rDNA and ITS region were amplified as a single amplicon. The amplification products were then digested with TaqI restriction enzyme. Restriction patterns were analyzed in a gel documentation system and the similarity between the strains was determined automatically. Results obtained from nine strains of Lactobacillus indicated that 16S-ITS
rDNA RFLP could differentiate these bacteria at species level.

\section{Materials and methods}

Strains and growth conditions

Reference strains Lactobacillus brevis (NRRL B-4527), Lactobacillus coryniformis ssp. coryniformis (NRRL B4391), Lactobacillus delbrueckii ssp. bulgaricus (NRRL B-548), Lactobacillus delbrueckii ssp. delbrueckii (NRRL B-443), Lactobacillus coryniformis ssp. torquens (NRRL B-4390), Lactobacillus curvatus (NRRL B-8768), Lactobacillus farciminis (NRRL B-4566), Lactobacillus fermentum (NRRL B-4524), and Lactobacillus pentosus (NRRL B-227) were obtained from Agricultural Research Service Culture Collection (ARS/NRRL; Peoria, IL., USA) and were kept at $-80{ }^{\circ} \mathrm{C}$ in $20 \%$ glycerol. The strains were grown in MRS agar, (peptone, $10 \mathrm{~g} / \mathrm{l}$; meat extract, $10 \mathrm{~g} / \mathrm{l}$; yeast extract, $5 \mathrm{~g} / \mathrm{l} ; \mathrm{D}(+)$-glucose, $20 \mathrm{~g} / 1 ; 0,1 \%$ (vol/vol) Tween 80; $\mathrm{K}_{2} \mathrm{HPO}_{4}, 2 \mathrm{~g} / \mathrm{l} ; \mathrm{Na}-$ acetate, $5 \mathrm{~g} / \mathrm{l}$; tri-ammonium citrate, $2 \mathrm{~g} / \mathrm{l} ; \mathrm{MgSO}_{4} \cdot 7$ $\mathrm{H}_{2} \mathrm{O} 0.2 \mathrm{~g} / 1 ; \mathrm{MnSO}_{4} \cdot 4 \mathrm{H}_{2} \mathrm{O}, 0.05 \mathrm{~g} / \mathrm{l} ; 15 \mathrm{~g} / 1$ agar, $\mathrm{pH}$ 6.6) for $24 \mathrm{~h}$ at $30^{\circ} \mathrm{C}$.

\section{Preparation of genomic DNA}

Two methods (Ausubel et al. 1994; Cardinal et al. 1997) were combined. Briefly, $5 \mathrm{ml}$ of overnight cultures were harvested and cells were suspended in $200 \mu \mathrm{l}$ sucrose solution ( $25 \%$ sucrose, $30 \mathrm{mg}$ lysozyme $/ \mathrm{ml}$ in TE). Samples were then incubated for $1 \mathrm{~h}$ at $37^{\circ} \mathrm{C}$. After the cell lysis, $370 \mu \mathrm{l}$ proteinase $\mathrm{K}$ solution $(1 \mathrm{mg}$ proteinase $\mathrm{K} / \mathrm{ml}$ in TE) and $30 \mu \mathrm{l}$ SDS solution (10\%) 
were added and the samples were further incubated for $1 \mathrm{~h}$ at $37^{\circ} \mathrm{C}$. Following deproteinization, $100 \mu \mathrm{l} \mathrm{NaCl}$ $(5 \mathrm{M})$ and $80 \mu \mathrm{l} \mathrm{CTAB} / \mathrm{NaCl}$ solution $(10 \%$ cetyltrimethylammonium bromide, $0.7 \mathrm{M} \mathrm{NaCl})$ were added and the samples were then incubated for $10 \mathrm{~min}$ at $65^{\circ} \mathrm{C}$. Chloroform extraction was performed twice using one equal volume of chloroform (chloroform/isoamyl alcohol, 24:1). DNA wool was obtained by the addition of isopropanol (one equal volume) and was then washed in $500 \mu \mathrm{l}$ ethanol $(70 \%)$. DNA was pelleted, dried, and dissolved in $100 \mu \mathrm{l}$ RNase solution (100 $\mu \mathrm{g} / \mathrm{ml}$ RNase in TE). After incubation for $1 \mathrm{~h}$ at $37^{\circ} \mathrm{C}$, the sample volumes were adjusted to $400 \mu \mathrm{l}$ with TE and DNA was solubilized by alternating heat shocks, for $10 \mathrm{~min}$ at $80^{\circ} \mathrm{C}$, and for $20 \mathrm{~min}$ at $-20^{\circ} \mathrm{C}$. Phenol/chloroform extraction was performed and DNA precipitated with $0.5 \mathrm{M} \mathrm{NaCl}$ (final concentration) and two volumes of ethanol $(99 \%)$. Pellets were washed in $500 \mu$ l ethanol $(70 \%)$. Finally DNA was solubilized as above in 50$250 \mu \mathrm{l} \mathrm{TE}$, depending on the solubility of the DNA pellet. Samples were stored at $-20{ }^{\circ} \mathrm{C}$.

\section{Amplification of the $16 S$ rDNA - ITS region}

Polymerase chain reactions were performed in a volume of $50 \mu \mathrm{l}$ containing approximately $500 \mathrm{ng}$ of genomic DNA as the template, $0.2 \mathrm{mM}$ dNTPs, $1.5 \mathrm{mM} \mathrm{MgCl}$, 10 pmol of each of the DNA primers, $1 \alpha \times$ PCR buffer (Fermentas), and $1.25 \mathrm{u} \mathrm{Taq}$ DNA polymerase (Fermentas). PCR conditions were as follows: an initial denaturation step for $5 \mathrm{~min}$ at $94{ }^{\circ} \mathrm{C} ; 40$ cycles of amplification including $1 \mathrm{~min}$ denaturation at $94{ }^{\circ} \mathrm{C}$, $1 \mathrm{~min}$ annealing at $42{ }^{\circ} \mathrm{C}$, and $1 \mathrm{~min}$ elongation at $72{ }^{\circ} \mathrm{C}$, steps. The reactions were terminated with a final extension step for $10 \mathrm{~min}$ at $72{ }^{\circ} \mathrm{C}$. Amplifications were performed in a Mini Cycler System (MJ Research INC, USA). DNA primers used in the experiments were, forward, 5'-AGAGTTTGATCCTGGCTCAG-3' (Mora et al. 1998) and reverse, 5'-CAAGGCATCCACCGT3' (Jensen et al. 1993). The forward primer is complementary to the upstream of $16 \mathrm{~S}$ rDNA of E. coli K12 strain (Accession number: AE000452, nucleotides from 1 to 20), and the reverse is complementary to the upstream sequences of 23S rDNA of E. coli 278710 (Accession number: AJ278710, nucleotides from 18 to 32 ).

\section{Restriction fragment length polymorphism (RFLP)}

One fourth of the amplification products, approximately $700 \mathrm{ng}$, were digested with 10 units of TaqI (Fermentas) restriction enzyme. Digestion samples were overlaid with mineral oil and carried out overnight in a water bath at $65{ }^{\circ} \mathrm{C}$. Before and after the digestion, DNA was extracted twice with chloroform and ethanol precipitated (Sambrook et al. 1989). Half of the restriction products were resolved in 2.5\% agarose (Applichem, low EEO) by gel electrophoresis for $2.5 \mathrm{~h}$ at $60 \mathrm{~A}$ in $1 \mathrm{x}$ TAE (40 mM Tris-acetate and $1 \mathrm{mM}$ EDTA $\mathrm{pH} 8.0$ ), and stained with ethidium bromide $(1 \mu \mathrm{g} / \mathrm{ml}$, final concentration). Image of the gel was recorded for further analysis in a gel documentation system (Vilber Lourmat, France).

\section{RFLP pattern analysis}

RFLP patterns were stored into and refined by Adobe Photoshop 7.0 and were then analyzed by using BIO$1 \mathrm{D}++$ software (Vilber-Lourmat, France). The similarity between strains was determined automatically by specifying the formula of Nei and Li (Vilber-Lourmat). Strain clustering was performed by the unweighted pair group method with arithmetic averages, UPMGA, (BIO-1D ++, Vilber-Lourmat).

\section{Results and discussion}

The length of $16 \mathrm{~S}$ rDNA-ITS amplification products varied from 1500 to $2000 \mathrm{bp}$. These fragments were purified and digested with three frequent cutter restriction enzymes: AluI, HaeIII, and TaqI. After chloroform extraction, digestion products were separated by agarose gel electrophoresis. In the report, only the results of TaqI restriction enzyme digestion were included because this enzyme was found to be the most discriminative among the three restriction enzymes used.

\section{RFLP with TaqI restriction enzyme}

RFLP with TaqI restriction enzyme could differentiate the nine Lactobacillus strains into three major groups (Figure $1 \mathrm{~A}-\mathrm{C}$ ). Group A contained five strains (lanes 1-5). Consistent with the expectations, two subspecies of Lb. coryniformis (lanes 1 and 2) produced identical restriction patterns, thus the similarity between them was $100 \%$. The $L b$. pentosus restriction pattern (lane 3 ) appeared to be the closest to those of the two Lb. coryniformis strains, with approximately $67 \%$ similarity. Lb. brevis and Lb. fermentum strains, on the other hand, yielded quite dissimilar digestion profiles within themselves (lanes 4 and 5, respectively), and they both were equidistant to the other members of the group. Two members of group B (lanes 6 and 7) were the two subspecies strains of Lb. delbrueckii and these also produced identical digestion profiles. Although included within the same group, $L b$. farciminis restriction profile (lane 8 ) showed only $50 \%$ similarity to those of $L b$. delbrueckii ssp. strains. The most outstanding feature of the pattern analysis was that the restriction profile of Lb. curvatus formed a group of its own (group C), and it appeared to be the most distant strain in the whole dendrogram.

Initially 150 local isolates of lactic acid bacteria (LAB), including both cocci and bacilli, were analyzed by $16 \mathrm{~S}$ rDNA RFLP, and it was not possible to unambiguously differentiate each species of LAB genera (data not shown). This problem prompted us to extend 


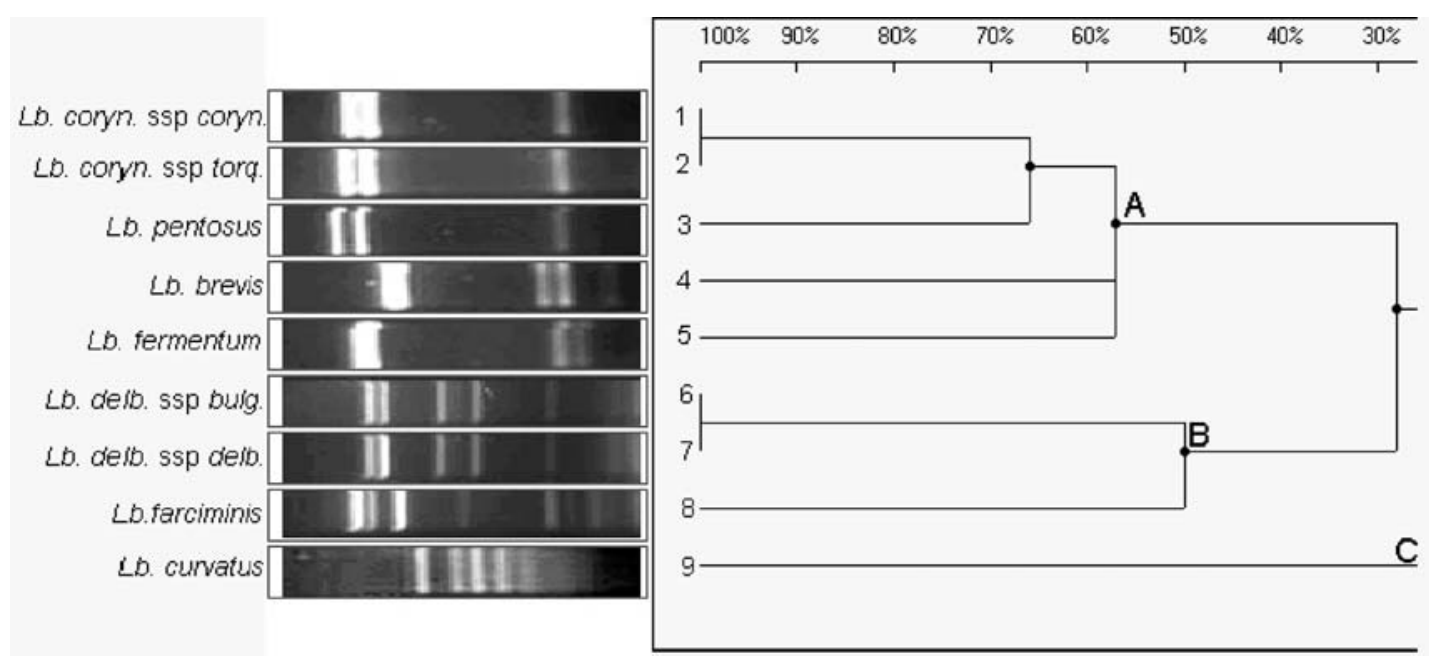

Figure 1. Cluster analysis of 16S rDNA-ITS RFLP profiles: The restriction profiles were produced with TaqI restriction enzyme. Strain names (left) were given with respective RFLP profiles (gel strips) and with the dendrogram. Lane 1, Lactobacillus coryniformis ssp. coryniformis (NRRL B-4391). Lane 2, Lactobacillus coryniformis ssp. torquens (NRRL B-4390). Lane 3, Lactobacillus pentosus (NRRL B-227). Lane 4, Lactobacillus brevis (NRRL B-4527). Lane 5, Lactobacillus fermentum (NRRL B-4524). Lane 6, Lactobacillus delbrueckii ssp. bulgaricus (NRRL B-548). Lane 7, Lactobacillus delbrueckii ssp. delbrueckii (NRRL B-443). Lane 8, Lactobacillus farciminis (NRRL B-4566) and lane 9, Lactobacillus curvatus (NRRL B-8768). Before the dendrogram, the bands within the each of the restriction profiles were normalised against a DNA size marker (1 kb DNA ladder, Fermentas).

the $16 \mathrm{~S}$ rDNA sequence down to the 5 -end of $23 \mathrm{~S}$ rDNA sequences, covering the whole ITS region. Results demonstrated that by using 16S rDNA-ITS RFLP it would be possible to discriminate species of Lactobacilli. Discriminative power of the approach should of course be revealed by further applications. The results also indicated that among the three frequent cutter restriction enzymes used, TaqI was the most discriminative enzyme.

\section{Acknowledgements}

This work was partially supported by grants from IYTE (2001FEN20; 2002IYTE43), TUBITAK (TBAG-1982/ 100T088), and from DPT (2002K-120/390). The Authors would like to thank Res. Assist. Mert Sudagidan for his assistance in the computational work.

\section{References}

Abd-El-Haleem, D., Layton, A.C. \& Sayler, G.S. 2002 Long PCRamplified rDNA for PCR-RFLP- and Rep-PCR-based approaches to recognize closely related microbial species. Journal of Microbiological Methods 49, 315-319.

Ausubel, F.M., Brent, R., Kingston, R.E., Moore, D.D., Seidman, J.G., Smith, J.A. \& Struhl, K. 1994 Current Protocols in Molecular Biology, vol. 3. John Wiley \& Sons, Inc. ISBN O-471-50337-1.

Cardinal, M.J., Meghrous, J., Lacroix, C. \& Simard, R.E. 1997 Isolation of Lactococcus lactis strains producing inhibitory activity againist Listeria. Food Biotechnology 11, 129-146.

Cho, J-C. \& Tiedje, J.M. 2000 Biogeography and degree of endemicity of fluorescent Pseudomonas strains in soil. Applied and Environmental Microbiology 66, 5448-5456.

Daffonchio, D., Borin, S., Consolandi, A., Mora, D., Manachini, P.L. \& Sorlini, C. 1998 16S-23S rRNA internal transcribed spacers as molecular markers for the species of the 16S rRNA group I of the genus Bacillus. FEMS Microbiology Letters 163, 229-236.

Daffonchio, D., Cherif, A. \& Borin, S. 2000 Homoduplex and heteroduplex polymorphisms of the amplified ribosomal $16 \mathrm{~S}-23 \mathrm{~S}$ internal transcribed spacers describe genetic relationships in the "Bacillus cereus group". Applied and Environmental Microbiology 66, 5460-5468.

Fisher, M.M. \& Triplett, E.W. 1999 Automated approach for ribosomal intergenic spacer analysis of microbial diversity and its application to freshwater bacterial communities. Applied and Environmental Microbiology 65, 4630-4636.

Garcia-Martinez, J., Acinas, S.G., Anton, A.I. \& Rodriguez-Valera, F. 1999 Use of the 16S-23S ribosomal genes spacer region in studies of prokaryotic diversity. Journal of Microbiological Methods 36, $55-64$.

Jensen, M.A., Webster, J.A. \& Strauss, N. 1993 Rapid identification of bacteria on the basis of polymerase chain reaction-amplified ribosomal DNA spacer polymorphisms. Applied and Environmental Microbiology 59, 943-952.

Luz, S.P., Rodriguez-Valera, F., Lan, R. \& Reeves, P.R. 1998 Variation of the ribosomal operon $16 \mathrm{~S}-23 \mathrm{~S}$ gene spacer region in representatives of Salmonella enterica subspecies. Journal of Bacteriology 180, 2144-2151.

Mora, B., Fortina, M.G., Nicastro, G., Parini, C. \& Manachini, P.L. 1998 Genotypic characterisation of thermophilic bacilli: a study on new soil isolates and several reference strains. Research in Microbiology 149, 711-722.

Sambrook, J., Fritsch, E.F. \& Maniatis, T. 1989 Molecular Cloning, A Laboratory Manual, 2nd edn. Cold Spring Harbor, NY: Cold Spring Harbor Laboratory Press. ISBN O-87969309-6.

Shaver, Y.J., Nagpal, M.L., Rudner, R., Nakamura, L.K., Fox, K.F. \& Fox, A. 2002 Restriction fragment length polymorphism of rRNA operons for discrimination and intergenic spacer sequences for cataloging of Bacillus subtilis sub-groups. Journal of Microbiological Methods 50, 215-223.

Toth, I.K., Avroka, A.O. \& Hyman, L.J. 2001 Rapid identification and differentiation of the soft rot erwinias by $16 \mathrm{~S}-23 \mathrm{~S}$ intergenic transcribed spacer-PCR and restriction fragment length polymorphism analyses. Applied and Environmental Microbiology 67, 40704076 . 